\title{
Perception of Household on Greening methods to Ameliorate Climate change in South-West of Oyo State
}

\author{
Oyewole, O.O; Ogunwale, O. G.; Ajanaku A. O. and Nwachi A. C.
}

Department of Agricultural Extension and Management, Federal College of Forestry, Ibadan . Nigeria

bollietee@yahoo.co.uk

\begin{abstract}
The project investigated the perception of household on greening methods to ameliorate climate change in south-west of Oyo state. The study was carried out in Oluyole local Government of Oyo state, Nigeria. Where two areas were randomly selected (Oluyole estate and Oluyole Extension). A total number of 91 structured questionnaires were retrieved out of 130 administered. Data collected were analyzed. Descriptive was used to analyzed socio economic characteristics, sources of information on greening, perception of respondent on greening, different greening method by the respondent and constraints, cross tabulation was used to explain association between socio characteristics and greening method and Pearson Product Moment Correlation (PPMC) was used to analyzed constraints and greening method by the respondents, relationship between the perception and greening method by the respondents. The result of the study revealed that majority of the respondents were male (65.9\%), and between the ages of 31-40 (34.2\%), majority also had tertiary education( $58.2 \%$ ) this showed that people within the study area were informed on the value of education, it was also revealed that majority of the respondent agreed that the human activities have led to climate change 3.51 mean value, Developing countries should take most of the blame for climate change (3.07) mean value and that laws governing the forestry management in Nigeria should be revisited with 2.03 mean value. Respondents agreed that planting oftrees, planting of tree crops, planting of flowers, planting of shrubs like Morida lucida, Moringa oleifera, Glyricidia sepium, management and development are the best method to ameliorate climate change, it was observed that deforestation, urbanization, industrialization, Lack of good policy by Federal Government are the major constraints. The use solar energy is the least that people use because majority are using generator which add carbon monoxide to the atmosphere. This study recommended that human
\end{abstract}

activities should be controlled in order to modify our environment, planting of trees, planting of tree crops like mango, cashew, orange, coconut will serve as fruit for family as well as improvement on climate change, planting of flowers for beautification and planting of shrubs are the best method to ameliorate climate change. Laws should be enacted to avoid climate change based on deforestation and good policies should be put to practice by Federal Government base on industrialization in urban areas.

Keywords-Climate change, greening, ameliorate.

\section{INTRODUCTION}

Climate change and agriculture are interrelated processes, both of which take place on global scale. (Jeremy, 2008).Climate change is one of the most serious environmental threats facing mankind world-wide, it affects agriculture in several ways, including its direct impact on food production. Climate change, which is attributable to the natural climate cycle and human activities as adversely affected agricultural productivity in Nigeria (Ziervogel and Easterling, 2006). The weather pattern changes caused by climate change is also as a result pollution in the environment. Greening is the process of taking a greater interest in environmental issues and acting to protect the environment (MPL;

2009-2017) (https://www.macmilliandictionary.com)

Wisner (2004), report that the vulnerability of agriculture is not determined by the nature and magnitude of environmental stress life climate change parse, but by the combination of the societal capacity to cope with or/recover from environmental change. While the coping capacity and degree of exposure is related to environmental changes, they are both also related to changes in societal aspects such as land use and cultural practices. Agriculture in Nigeria is predominantly in the hands of rural small holder farmers, who have been generally described as poor and hungry. Some of the ways to improve living a green lifestyle and to 
ameliorate climate change include adopting the reuse recycle principle, energy saving practices. There are many energy efficient practices and appliances that you can use to turn your home into a green, energy efficient home. Reduction of pollution by reducing the use of harmful chemicals and substances in your home, and using eco friendly home cleaners and other eco-friendly products in your daily needs, Introduction of more plants and trees into our environment and encourage others to do the same. Growing of green garden using green gardening principles, or even plant trees in your name. Check out the tips you can adopt for daily green living for the home, including tips for green household cleaning and tips for recycling, and find out where you can find green household products and green gifts. (Onuoha,2009).

Energy conservation will show the earliest payback in terms of $\mathrm{CO} 2$ reductions in many cases an investment in energy conservation made this year will show $\mathrm{CO} 2$ reductions this year, and every year thereafter. Because we've been living in a world of artificially cheap energy for decades, there are huge opportunities for energy conservation (Onuoha, 2009). A Forestation has a vital role to play in the fighting against global warming. Forests absorb and store carbon in their trees and soil. But if forests are cleared or disturbed, this carbon is released as carbon dioxide and other greenhouse gases. Up to a fifth of global greenhouse gas emissions come from deforestation and forest degradation, (Akinbami, 2003).

The general Objective is to determine the perception of household on greening methods to ameliorate climate change in South West Local Government Area of Oyo State Nigeria .

\section{Specific Objectives}

1. To examine the socio-economic characteristics of the respondents in the study area.

2. To determine the perception of respondents on greening

3. To ascertain source of information on greening by the respondent

4. To identify constraints faced by respondents in the study area.

Hypotheses of the Study

Ho1: There is no significant relationship between socio economic characteristics and th greening method practiced

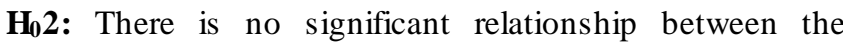
constraints and greening method by the respondent

Ho3: There is no significant relationship between perception and greening method

\section{METHODOLOGY}

The study was carried out in Ibadan south West is a Local Government area in Oyo State, Nigeria. Its headquarters are at Oluyole Estate in Ibadan. It has an area of $40 \mathrm{~km}^{2}$ and a population of 282,585 (census 2006)The target population of this study were people living in Oluyole Estate and Oluyole Extension area of Ibadan South -West of Oyo State.

The data collection of this project work was primary source of data collection from the people living in Oluyole Estate and Oluyole Extension area of Ibadan South -West of Oyo State, with the use of personal interview and questionnaires due to the practicing of greening on climate improvement. Random sampling technique was used to carry out this research work in Ibadan South- West of Oyo State, with total number of 130 well-structured questionnaires were distributed and 91 were retrieved.

Respondent were asked to respond to some of the greening method practice base on 3point scale Eleven greening method question were listed, hence, the highest mean value obtained was 2.59 while the lowest mean value was 2.25 .

\section{RESULT AND DISCUSSION}

The result revealed that male with $65.9 \%$ are into greening practices more than female $34.1 \%$. This can be attributed to the fact that male headed household are more than household headed by female this in line with (Arnold, 2009). This implies that respondents of younger generation are more enlightening about climate change more than older generation. The result also reveal that $20.9 \%$ of the respondents are within age of $20-30,34.1 \%$ of the respondents are within the range of $31-40$, and $28.6 \%$ within the range of $41-50,16.5 \%$ are within the range of 51 above, this result indicate that more adult are involve in greening practice than the youth and this would increase the knowledge of the greening practice. This project supports the work of (Madhur, 2006) that adults are into greening practice than younger people in Africa. The table also indicates that $65.9 \%$ of the respondents are married, $8.8 \%$ are widow and $25.3 \%$ of the respondents are single in the study area which shows that majority of the respondents are adult..

According to the result $58.2 \%$ have tertiary education, and $30.8 \%$ had secondary education, while $6.6 \%$ had primary education and $4.4 \%$ had no formal education. This shows that people within the study area are informed on the value of education and this will surely add to the knowledge the residents have on climate change, the level of education could also be as a result of enabling people to make decision regarding production and managing their lives 
successfully to cope with everyday problems and to realize their opportunities (Swanson 2008).

Finally, $76.9 \%$ of the respondents have1-5, $19.8 \%$ and between 6-10children, while $3.3 \%$ has above 10 children. This shows that respondents in the study area are interested in their family size.

The result on sources of information on greening climate change revealed that majority of the respondents heard about climate change from the scientist with mean value (3.70) likewise Radio which is mass media source of information. This work is in line with Adekunle (1996). The use of media to spread information like Radio, local TV and projector are best tools in disseminating information.

Furthermore, the result shows the mean value 3.34 of the respondents heard of climate change through Government agency this is in support of Enger et al., 2012 that government are also good source of transforming information to the citizen through the agencies.

Lastly, less people heard of climate change through friends with the mean value of 3.13 and mean value of 2.53 heard of climate change through local council. This also support the study of Boz and Ozcatalbas (2010) which revealed that family members, neighbor friends, input providers and mass media were key sources of information in Nigeria. Table 3 shows that $(76.92 \%)$ of the respondents have access to information on climate change in the study area while $(23.08 \%)$ of the respondents had lesser information on climate change. This implies that the high source of information in the study area contribute to practice greening to ameliorate climate change.

Table.1: The Socio Economic Characteristics of the Respondents

\begin{tabular}{|c|c|c|}
\hline Variable & Frequency $(\mathrm{n}=91)$ & Percentage \\
\hline \multicolumn{3}{|l|}{ Gender } \\
\hline Male & 60 & 65.9 \\
\hline Female & 31 & 34.1 \\
\hline \multicolumn{3}{|l|}{ Age } \\
\hline $20-30$ & 19 & 20.9 \\
\hline $31-40$ & 31 & 34.1 \\
\hline $41-50$ & 26 & 28.6 \\
\hline 51above & 15 & 16.5 \\
\hline \multicolumn{3}{|l|}{ Religion } \\
\hline Christian & 71 & 78.0 \\
\hline Islamic & 20 & 22.0 \\
\hline \multicolumn{3}{|l|}{ Marital Status } \\
\hline Single & 23 & 25.3 \\
\hline Married & 60 & 65.9 \\
\hline Widow & 8 & 8.8 \\
\hline \multicolumn{3}{|l|}{ Educational level } \\
\hline No formal education & 4 & 4.4 \\
\hline Primary & 6 & 6.6 \\
\hline Secondary & 28 & 30.8 \\
\hline Tertiary & 53 & 58.2 \\
\hline \multicolumn{3}{|l|}{ Household } \\
\hline $1-5$ & 70 & 76.9 \\
\hline $6-10$ & 18 & 19.8 \\
\hline 10above & 3 & 3.3 \\
\hline
\end{tabular}

Source: Field survey, 2016. 


\begin{tabular}{lccccc}
\hline \multicolumn{1}{c}{ Source of information } & No & Rarely & Occasionally & Regularly & Mean value \\
\hline Scientist & $1(1.1)$ & $6(6.6)$ & $12(13.2)$ & $72(79.1)$ & 3.70 \\
Radio & $1(1.1)$ & $4(4.4)$ & $27(29.7)$ & $59(64.8)$ & 3.58 \\
Newspaper & $6(6.6)$ & $8(8.8)$ & $17(18.7)$ & $60(65.9)$ & 3.43 \\
Television & $7(7.7)$ & $6(6.6)$ & $20(22.0)$ & $58(63.7)$ & 3.41 \\
Government agency & $1(1.1)$ & $12(13.2)$ & $33(36.3)$ & $45(49.5)$ & 3.34 \\
Pastor/cleric & $8(8.8)$ & $9(9.9)$ & $25(27.5)$ & $49(53.8)$ & 3.26 \\
Environmental organization & $10(11.0)$ & $10(11.0)$ & $25(27.5)$ & $46(50.5)$ & 3.17 \\
Family/ & $4(4.4)$ & $20(22.0)$ & $26(28.6)$ & $41(45.1)$ & 3.14 \\
Friends & $6(6.6)$ & $15(16.5)$ & $31(34.1)$ & $39(42.9)$ & 3.13 \\
Local council & $20(22.0)$ & $27(29.7)$ & $19(20.9)$ & $25(27.5)$ & 2.53 \\
\hline
\end{tabular}

Field survey, 2016.Percentage in parenthesis:

Table.3: Categorization of Sources of Information on Greening Climate Change

\begin{tabular}{lll}
\hline Level of Information & Frequency & Percentage \\
\hline HIGH & 70 & 76.92 \\
LOW & 21 & 23.08 \\
TOTAL & 91 & 100 \\
\hline
\end{tabular}

\section{Perception of Respondent on Greening}

The result on the level of perception of the respondent in the study area to amelioration of climate change in Oluyole Local Government Area. it was revealed that majority of the respondent agreed that the human activities have effect about climate change with mean value of (3.51), this is in support of Zievogel and Easterling, 2006, which says that either directly or indirectly, human has effect on climate change in Nigeria. The result also showed that developing countries should take most of the blame for climate change with mean value (3.07) this is in line with Nwafor and Ologunorisa, 2007, that the available research shows that climate change is global, likewise its impacts, but the most agent in term of countries are developing once, due to improved technologies introduce to Nigeria.
Government should re- visit law governing the forestry management in Nigeria which has a mean value of (2.03), this in line with Enger et. al 2012 that government should provide adequate incentive and management of environment in Nigeria to combat climate change.

Lastly, the respondents agreed that they can all do their best to reduce climate change with least mean value of (1.51), this is in line with Birner and Allison (2006), that both men and women are entitled to modify their environment through the use of flowers, lawns, trees etc. to improve climate change in Nigeria.

Table 5 shows that there is low perception on greening $(53.85 \%)$ of the respondents and there is low perception on greening $(46.15 \%)$ of the respondents.

Table.4: Perception of Respondent on Greening

\begin{tabular}{|c|c|c|c|c|c|c|}
\hline Variables & SA & A & $\bar{U}$ & $\mathrm{D}$ & SD & Mean value \\
\hline $\begin{array}{l}\text { Human activities have effect about climate } \\
\text { change. }\end{array}$ & $18(19.8)$ & $5(5.5)$ & $10(11.0)$ & $28(30.8)$ & $30(33.0)$ & 3.51 \\
\hline $\begin{array}{l}\text { Developing countries should take most of } \\
\text { the blame for climate change. }\end{array}$ & $20(22.0)$ & $15(16.5)$ & $13(14.3)$ & $24(26.4)$ & $19(20.9)$ & 3.07 \\
\hline Having a car is part of good lifestyle. & $17(18.7)$ & $28(30.8)$ & $13(14.3)$ & 16 (17.6) & 17 (18.7) & 2.86 \\
\hline $\begin{array}{l}\text { Climate change is just a natural fluctuation } \\
\text { in earth's temperature. }\end{array}$ & $27(29.7)$ & $30(33.0)$ & $8(8.8)$ & $9(9.9)$ & 17 (18.7) & 2.54 \\
\hline $\begin{array}{l}\text { National government should limit industrial } \\
\text { activities in the country. }\end{array}$ & $25(27.5)$ & $30(33.0)$ & $11(12.1)$ & $18(19.8)$ & $7(7.7)$ & 2.47 \\
\hline I will only do my bit to reduce climate & $19(20.9)$ & $47(51.5)$ & $3(3.3)$ & 14 (15.4) & $8(8.8)$ & 2.39 \\
\hline
\end{tabular}


change if everyone else did as well.

It is inevitable because of modern society work.

Humans are severely abusing the planet. $33(36.3)$ $28(30.8)$ $10(11.0)$ $9(9.9)$

$11(12.1)$ 2.30

Should government provide incentives for $42(46.2)$ 17(18.7)

17 (18.7)

$4(4.4)$

$11(12.1)$ people to look after the environment as to reduce effect of climate change?

Government should re- visit law governing the forestry management in Nigeria.

Humans have the right to modify the natural environment to suit their needs.

Greening will improve weather $38(41.8) \quad 33(36.3)$

$5(5.5)$ $8(8.8)$

2.03

Do you think anything can be done to tackle $39(42.9)$ $28(30.8)$

$10(11.0)$

$10(11.0)$

$4(4.4)$

2.03

47 (51.6)

27 (29.7)

$5(5.5)$

$9(9.9)$

$3(3.3)$

1.83

$45(49.5)$

29 (31.9)

$7(7.7)$

$7(7.7)$

$3(3.3)$

1.83

39 (42.9)

$42(46.2)$

$3(3.3)$

$6(6.6)$

$1(1.1)$

1.76

greenish effect

we can all do our best to reduce climate

$60(65.9)$

$22(24.2)$

$2(2.2)$

$7(7.7)$

1.51 change

Percentage in parenthesis source: Field survey, 2016

Table.5: Categorization of Perception on Greening

\begin{tabular}{ccc}
\hline Perception & Frequency & Percentage \\
\hline HIGH & 42 & 46.15 \\
LOW & 49 & 53.85 \\
TOTAL & 91 & 100 \\
\hline
\end{tabular}

\section{Source: Field Survey, 2016}

The Different Greening Method Practice by Respondent was measured where majority of the respondent agreed that the planting of trees is the best method with mean value (2.59) and this is in line with Biner,2006, that both men and women are entitled to modify their environment through the use of flowers, lawns, trees etc. to improve climate change in Nigeria. Also the use of planting tree crops in environment with mean value (2.58) will ameliorate climate change and serve as a fruits for the family as well likewise the management and development of forestry can also be used to reduce climate change which has a mean value (2.45) and this statements is in support of Adams 2011, that forestry management is of good benefit through the releasing of $\left(\mathrm{O}_{2}\right)$ oxygen to air for consumption of human being in relating to climate change in Nigeria.

Lastly, the use of solar energy to generate power has mean value of (2.27) and this can also reduce climate change which will reduce the use of generator in the environments and will minimize climate change from the release of carbon monoxide to the atmosphere and, stopping the use of chemical that can cause depletion of ozone to environment has mean value of (2.25). This also is in line with, Ogboi
2012, wherehe stated that activities of man emitted some poisonous elements such as carbons ( $\mathrm{Co}_{2}$ and $\left.\mathrm{Co}\right)$ sulphur, methane, nitrogen oxide, chlophlorocarbon (CFCs) etc.

The result on constraints to greening practices gives a mean value of (1.63) where the majority of the respondents strongly disagree that farming activities is not affecting climate change but contributed to improvement of climate in Nigeria. Also majority of the respondent agreed with mean value (1.23) that poverty is also constraint, this result is in line with (Wolfe et al, 2005) that wide-ranging effects of climate change on many facets of human societies such as poverty, and human activities. Deforestation with mean value of (1.16) is a constraint facing climate change where it was clearly showed that deforestation is a part of challenge facing climatic change in Nigeria due to increase in urbanization, Adams 2011.

The least constraints were discussed where Industrialization has mean value of (1.12) which is part of human activities and lastly lack of good policy by federal Government which is drastically affecting human in terms of improving climate change which has mean value of (1.10). 


\begin{tabular}{|c|c|c|c|c|}
\hline Variables & Rarely & Occasionally & Regularly & Mean value \\
\hline By planting of trees & $6(6.6)$ & $25(27.5)$ & $60(65.9)$ & 2.59 \\
\hline By planting of tree crops & $5(5.5)$ & $28(30.8)$ & $58(63.7)$ & 2.58 \\
\hline By planting of flowers for beautification & $11(12.1)$ & $19(20.9)$ & $61(67.0)$ & 2.54 \\
\hline By management and development of forestry & $15(16.5)$ & $20(22.0)$ & $56(61.5)$ & 2.45 \\
\hline By reducing cutting down of trees & $15(16.5)$ & $24(26.4)$ & $52(57.1)$ & 2.40 \\
\hline By establishing of lawn & $15(16.5)$ & $24(26.4)$ & $52(57.1)$ & 2.40 \\
\hline The use of trees for fencing & $14(15.4)$ & $27(29.7)$ & $50(54.9)$ & 2.39 \\
\hline By planting of vegetable garden & $13(14.3)$ & $31(34.1)$ & $47(51.6)$ & 2.37 \\
\hline By planting of shrubs & $13(14.3)$ & $36(39.6)$ & $42(46.2)$ & 2.31 \\
\hline The use of solar energy to generate power & $11(12.1)$ & $44(48.4)$ & $36(39.6)$ & 2.27 \\
\hline $\begin{array}{l}\text { By stopping the use of chemical that can cause } \\
\text { depletion of ozone layer }\end{array}$ & $23(25.3)$ & $22(24.2)$ & $46(50.5)$ & 2.25 \\
\hline
\end{tabular}

Percentage in parenthesis source: Field survey, 2016.

Table.7: Constraints to Greening Practices.

\begin{tabular}{lccc}
\hline Variables & Yes & No & Mean value \\
\hline Farming activities & $33(36.3)$ & $58(63.7)$ & 1.63 \\
Poverty & $61(67.0)$ & $30(33.0)$ & 1.32 \\
Environmental dynamic & $69(75.6)$ & $22(24.1)$ & 1.24 \\
High energy supply & $70(76.9)$ & $21(23.1)$ & 1.23 \\
Lack of commitment by people & $74(81.3)$ & $17(18.7)$ & 1.18 \\
Deforestation & $76(83.5)$ & $15(16.5)$ & 1.16 \\
Urbanization & $77(84.6)$ & $14(15.4)$ & 1.15 \\
Increased temperature & $77(84.6)$ & $11(12.1)$ & 1.15 \\
Industrialization & $80(87.9)$ & $10(11.0)$ & 1.10 \\
Lack of good policy by federal Government & $81(89.0)$ & & \\
\hline
\end{tabular}

\section{Source: Field survey, 2016. Percentage in parenthesis}

\section{HYPOTHES ES TESTING}

Table.8: Socio-economic characteristics of respondents and their attitudes toward sustainable urban vegetable farming

\begin{tabular}{llll}
\hline Variable & $\chi^{2}-$ value & p-value & Decision \\
Age & 8.630 & 0.259 & Not significant \\
Sex & 0.546 & 0.077 & Not significant \\
Religion & 3.880 & 0.206 & Not significant \\
Marital status & 4.743 & 0.042 & Significant \\
Education & 3.866 & 0.063 & Not significant \\
Household size & 1.726 & 0.135 & Not significant \\
\hline
\end{tabular}

Table.9: PPMC Analysis of the Constraints and Greening Method by the Respondents

\begin{tabular}{lll}
\hline Variable & r-value & p-value \\
\hline Constraints and greening method by the respondents & .003 & -.310
\end{tabular}

Source: field survey, 2016

The table above shows that there is no significant relationship between the constraint and greening method by the respondents where the r-value is .003 and p-value is -.310 which is greater at $5 \%$ level. 
Table.10: PPMC Showing Relationship between the Perception and Greening Method by the Respondents

\begin{tabular}{llll}
\hline Variable & r-value & p-value & Decision \\
\hline Perception and greening method by the respondents & -0.400 & 0.000 & $\mathrm{~S}$ \\
\hline
\end{tabular}

Source: field survey, 2016

Significant at $5 \%$

The table showed that there was significant relationship between constraints and greening method by the respondents $(\mathrm{p}<0.000, \mathrm{r}=0.400)$. This implies that $\mathrm{Ho}_{3}$ rejected

\section{CONCLUSION AND RECOMMENDATION}

It was observed that information on climate change was majorly heard by scientist in the study area. Human activities have effect on climate change and we can all do our best to reduce climate change because both men and women are entitled to modify our environment. Planting of trees and planting of trees and planting of tree crops are the best method to ameliorate climate change and the use of solar energy is the least that people use because majority are using generator which add carbon monoxide to atmosphere Planting of trees will reduce climate change also planting of lawns, flowers etc. Planting of tree crops such as orange, coconut, cashew etc. which will serve as fruit for family as well as improvement on climate change. Law should be provided to avoid climate change based on deforestation. Good policies should be put to practice by Federal Government base on industrialization in urban areas.

\section{REFERENCES}

[1] Adams R. M. (2011): Agriculture, forestry and related benefits of air pollution control. Am J Agric. Econ 68:885-894.

[2] Adekunle, O. O. (1996): Radio Listenership pattern and knowledge of improved farm practices (Unpublished B.Sc. Thesis). Department of Agricultural Extension and Services; University of Ibadan.

[3] Akinbami, J. (2003): "An Integrated Strategy for Sustainable Forest-energy-environment Interactions in Nigeria." Journal of Environmental Management 69.2 (2003): 115- 28.

[4] Birner. A.E and Allison, F.E. (2006): Extension service in African. Journal of agriculture and Extension Service. Vol. 8P p.13. Revised $24^{\text {th }}$ may, 2015.

[5] Boz, I., Ozcatalbas,O. and Babu I (2010): Determining information sources used by crop producers: A case study of Gaziantep province in Turkey. African Journal of Agricultural Research. 10(15): 271-272.
[6] Jeremy H, (2008): Tropical Deforestation, is one of the worst crisis, since we come out of the caves. Retrieved from (source) www. Monga ba u...com (2011).

[7] Madhur, H. (2006): Information and communication technologies for rural development and food security: Lesson from field experiences in Developing countries. J. African Sci. Society Vol.5, pp. 747-754.

[8] Nwafor S.O. and Ologunorisa T.E (2007): Global climate change: The driver of multiple causes of flood intensity in sub-Saharan Africa. Paper presented at the international conference on climate change and economic sustainability herd at Nnamdi Azikwe University Enugu, Nigeria 12 - 14 June 2007.

[9] Ogboi K.C (2012): An overview of climate change: causes processes and manifestations. Paper presented on $14^{\text {th }}$ edition of NITP/ TOPREC

[10] Onuoha, C.M. (2009): Climate Change and Sustainable Development in Nigeria: The Mitigating Role of Green Wall Sahara Nigeria Programme, African Institute for Applied Economics (AIAE) Enugu forum policy paper 10.

[11] Swanson, B. (2008): Global Review of Good Agricultural Extension and Advisory Service Practices. Rome: FAO. Vol.5 (10), 980-987. Retrieved on July $1^{\text {st }} 2015$.

[12] Wolfe D.W, MD Schwartz, A. Lakso, Y Otsuki, RM Pool and NJ Shaulis. ( 2005): Climate change and shifts in spring phenology of three horticultural woody perennials in northeastern USA. Internet $J$ Biometeorology 49:303-309. Meteorological Organization, Geneva

[13] Ziervogel M, and Easterling, C (2006): Climate variability and change. Implication for household food security. Assessments of impacts and adaption to climate change (AIACC) working paper NO 20. January 2006. The AIACC project office, international START secretariat Washington DC, USA 